E-ISSN. 2685-7650

Vol. 2 No. 1 (2020), pp 56-66

DOI: https://doi.org/10.33366/jkn.v2i1.40

\title{
Pencarian Informasi oleh Foodie pada Foto Makanan di Instagram
}

\author{
Monika Pretty Aprilia \\ Program Studi Ilmu Komunikasi, Universitas Amikom Yogyakarta \\ Email: monika.aprilia@amikom.ac.id
}

\begin{abstract}
Information seeking reduces uncertainty. Information is needed by human for work needs and other daily activities. One of these activities is a hobby. Many people spend a lot of time and money when they seek information for a hobby rather than for work. Foodie is a person who loves food. Foodie is interested in learning and trying new food. When someone is called a foodie then they must be someone who loves to taste food. A foodie also needs information to be able to taste various food. Social media has become one of information sources used by foodie to get information that related to food. This research shows the process of information seeking by foodie on food photos in Instagram. This study used consumer behavior in the prepurchase stage of service consumption from Tsiotsou and Wirtz's theory. Its method was descriptive qualitative by interviewing five foodies who live in Jakarta. Research result shows that Instagram is the main source for foodie when they seek information that related to food such as dining place information.
\end{abstract}

Keywords: information seeking, foodie, food photos, Instagram, pre purchase

\begin{abstract}
Abstrak: Pencarian informasi dilakukan untuk mengurangi ketidakpastian pada diri manusia. Informasi dibutuhkan manusia untuk kebutuhan pekerjaan maupun aktivitas lain yang dilakukan sehari-hari, salah satunya hobi. Banyak orang mengeluarkan banyak waktu serta dan saat mencari informasi untuk hobi daripada untuk pekerjaan. Foodie, merupakan orang yang menyukai makanan dan tertarik untuk belajar dan mencoba makanan baru. Seseorang yang disebut sebagai foodie adalah seseorang yang hobi mencicipi makanan. Seorang foodie juga membutuhkan informasi untuk bisa mencicipi berbagai makanan. Media sosial menjadi salah satu sumber informasi yang digunakan foodie untuk mendapatkan informasi. Penelitian ini melihat proses pencarian informasi oleh foodie pada foto makanan di Instagram. Penelitian ini menggunakan konsep perilaku konsumen pada tahap pra pembelian pada konsumsi pelayanan dari Tsiotsou dan Wirtz untuk melihat cara pencarian informasi yang dilakukan oleh foodie. Metode yang digunakan adalah deskriptif kualitatif dengan mewawancarai 5 orang foodie yang berdomisili di Jakarta. Penelitian menunjukkan Instagram menjadi sebagai sumber utama pencarian informasi tentang makanan yang dilakukan foodie. Salah satunya adalah informasi tentang tempat makan.
\end{abstract}

Kata kunci: pencarian informasi, foodie, foto makanan, Instagram, pra pembelian

\section{Pendahuluan}

Penelitian-penelitian tentang pencarian informasi pada beberapa dekade silam lebih banyak fokus pada pengembangan untuk membantu pekerjaan manusia, seperti sistem informasi komputer, perpustakaan, organisasi, pemasaran, dan masih banyak lagi. Padahal, dalam kehidupan nyata, manusia juga membutuhkan informasi yang tidak hanya terkait dengan pekerjaan (nonwork) seperti infomasi kesehatan, perencanaan keuangan, hobi dan masih banyak lagi.

Savolainen adalah ilmuwan pertama yang menjabarkan konsep Everyday Life of Information Seeking (ELIS), sebuah konsep yang muncul dari hasil penelitian yang dilakukan pada warga Finlandia dalam mencari informasi terkait kehidupan sehari-hari. Dalam hasil penelitiannya, terungkap bahwa manusia membuat prioritas dalam hidupnya. Prioritas tersebut disusun karena kebiasaan berpikir, persepsi dan evaluasi yang dilakukan setiap orang (Savolainen, 2017). Orang bisa menentukan kegiatan yang dipilih saat mendapatkan waktu luang, termasuk 


\section{Jurnal Komunikasi Nusantara}

\section{E-ISSN. 2685-7650}

Vol. 2 No. 1 (2020), pp 56-66

DOI: https://doi.org/10.33366/jkn.v2i1.40

memilih informasi dan sumber informasinya. Seseorang seringkali lebih berusaha mencari informasi untuk aktivitas di waktu luang seperti hobi daripada untuk pekerjaan/ tugas.

Foodie, dikenal sebagai orang yang menyukai dan tertarik untuk belajar tentang makanan (Delong, 2006). Johnston dan Baumann (2010) menyebutkan bahwa mereka yang disebut sebagai foodie memiliki empat karakteristik. Ada empat karakteristik yang dimiliki seorang foodie, yaitu identitas, pengetahuan, eksplorasi dan evaluasi. Karakteristik-karakteristik inilah yang menggambarkan bahwa foodie juga melakukan pencarian informasi, untuk memenuhi rasa ingin tahu tentang makanan, mencoba menu baru dan memberikan evaluasi atas makanan yang dicicipinya.

Seperti hobi lain pada umumnya, seorang foodie juga melakukan pencarian informasi secara internal maupun eksternal. Artinya foodie memiliki keinginan dari dirinya seperti motivasi atau rasa ingin tahu hingga terdorong untuk melakukan pencarian informasi secara eksternal seperti bertanya pada orang lain atau menelusuri di internet. Apabila seorang foodie ingin mencicipi suatu makanan, maka hal yang dilakukan sebelumnya adalah mencari dan mengumpulkan informasi.

Dalam beberapa literatur, salah satunya Zycherman (2013) menjelaskan bahwa foodie identik dengan identitas yang melekat pada orang-orang kelas menengah yang tertarik pada makanan melebihi orang-orang pada umumnya. Makanan, minuman dan memasak tidak sekadar konsumsi biasa untuk seorang foodie. Mereka melihat hal tersebut sebagai aktivitas seorang intelektual dan juga aktivitas yang reflektif (Richards, 2012 dalam Thanarugchok, 2017).

Seorang foodie memiliki karakteristik sesuai dengan definisi di atas. Karakteristik tersebut antara lain menyukai makanan, minuman serta aktivitas memasak. Foodie juga bisa dikategorisasikan berdasarkan aktivitas yang dilakukannya. Salah satu aktivitas yang melekat pada foodie adalah makan di luar rumah (eating out) seperti di restoran, kedai atau kafe. Thanarugchok (2017) menjelaskan bahwa banyak hal yang menjadi pertimbangan seorang foodie untuk makan di luar rumah. Beberapa hal di antaranya adalah kualitas makanan, suasana restoran, dan reputasi chef (Watson, Morgan, \& Hemmington, 2008 dalam Thanarugchok, 2017).

Penelitian ini hadir untuk menangkap fenomena makanan yang kini tidak lagi sekadar memenuhi kebutuhan hidup di era digital seperti sekarang ini. Kehadiran media sosial mengubah cara-cara foodie dalam melakukan pencarian informasi tentang makanan. Hartman (2012) dalam penelitiannya menjelaskan media sosial meningkatkan rasa ingin tahu dan menyediakan sumber informasi yang aman ketika seseorang mencari informasi tentang restoran, menu makanan dan teknik memasak. Seseorang bisa membeli makanan tanpa harus menyentuh, mencium atau mencicipi terlebih dahulu. Dengan cukup melihat foto makanan yang ada di media sosial, orang bisa membayangkan rasa makanan dari foto yang dilihatnya. Selain itu, mereka juga membaca opini secara online dalam proses keputusan untuk mencicipi makanan tersebut atau tidak.

Dalam survey yang dilakukan Zizi pada 2013 (The Argus, 2017) menunjukkan bahwa media sosial menjadi sumber utama dalam pencarian informasi restoran di London, Inggris. Anak muda berusia 18-35 tahun di London menghabiskan waktu lebih dari dua jam per minggunya untuk menelusuri foto makanan di Instagram. Media sosial ini digunakan anak muda di London sebagai sumber informasi sebelum memutuskan untuk makan di suatu restoran. Sebanyak 30\% responden mengaku mencari informasi restoran melalui Instagram terlebih dahulu (Zizi, 2013 dalam The Argus, 2017). 


\section{Jurnal Komunikasi Nusantara}

\section{E-ISSN. 2685-7650}

Vol. 2 No. 1 (2020), pp 56-66

DOI: https://doi.org/10.33366/jkn.v2i1.40

Secara akademis, penelitian ini diharapkan dapat menyajikan gambaran secara detil tentang proses yang dilakukan foodie dalam mencari informasi dengan media sosial Instagram. Sejauh ini, penelitian tentang foto makanan di media sosial lebih banyak fokus kepada mereka yang mengunggah foto makanan ke media sosial. Oleh karena itu, penelitian ini lebih melihat pada penggunaan Instagram untuk pencarian informasi, khususnya yang dilakukan oleh para pengguna media baru yang memiliki hobi tertentu seperti foodie.

Selain itu, penelitian tentang pencarian informasi yang terkait dengan mereka yang memiliki hobi terkait makanan sejauh ini masih sedikit. Salah satunya penelitian tentang hobi menulis makanan di blog (foodblogging) yang merupakan serious leisure (Cox \& Blake, 2011). Hasil penelitian yang menggunakan konsep dari sistem informasi tersebut menunjukkan bahwa foodblogging bisa menjadi sumber informasi baru yang juga bisa menciptakan inspirasi bagi yang membaca. Serta penelitian kedua tentang pencarian informasi yang dilakukan oleh seorang gourmet yang dilakukan oleh Hartel (2010). Penelitian ini merupakan hasil wawancara mendalam dengan 20 orang yang memiliki hobi memasak gourmet di rumah. Hasil penelitian ini mengembangkan adanya perpustakaan kuliner secara personal. Perpustakaan kuliner ini merupakan konstelasi sumber informasi tentang memasak dan juga gourmet yang bisa dimanfaatkan secara optimal untuk menambah pengetahuan para hobbyist gourmet.

Penelitian ini diharapkan dapat memberikan gambaran tentang foodie sebagai sebuah hobi yang juga membutuhan informasi. Seseorang disebut sebagai foodie karema aktivitas yang dilakukannya. Dalam konteks penelitian ini aktivitas foodie yang mengkonsumsi, khususnya makan di luar rumah seperti restoran (eating out site). Gambaran yang diharapkan adalah proses seorang foodie dalam mencari informasi tentang suatu makanan atau tempat makan.

Mengacu pada hasil penelitian tersebut, penelitian ini juga fokus pada aktivitas seseorang dalam menggunakan Instagram sebagai media sumber informasi. Kebaruan penelitian ini berada pada pemilihan subyek risetnya, yaitu foodie. Selain itu, kebaruan riset ini terletak pada penggunaan Instagram sebagai sumber pencarian informasi tentang makanan.

Karakteristik seorang foodie bisa dilihat dari aktivitas yang dilakukannya. Johnston dan Baumann (2010) menyebutkan bahwa salah satu karakteristik foodie, yaitu eksplorasi, menunjukkan seorang foodie memiliki minat untuk terus mencari pengalaman baru melalui aneka makanan dari berbagai tempat. Dalam karakteristik eksplorasi, seorang foodie selalu mengumpulkan berbagai informasi terkait dengan makanan yang ingin dicicipinya.

Sebagai sebuah hobi yang melibatkan aktivitas konsumsi, maka proses pencarian informasi yang dilakukan foodie dilihat dengan konsep pra pembelian. Dalam konsep tersebut, dilihat lebih lanjut proses dan cara yang dilakukan foodie dalam mencari informasi sebelum memutuskan datang ke sebuah tempat makan dan makan di tempat tersebut. Konsep pra pembelian yang diambil dari pemaparan Tsiotsou dan Wirtz (2015) tersebut ada tiga tahapan yang meliputi, pengenalan kebutuhan, penelusuran informasi, dan evaluasi terhadap informasi.

Tsiotsou dan Wirtz (2015) menggambarkan dalam model pra pembelian yang dilakukan pada konsumsi jasa pelayanan. Konsep ini digunakan karena di sini tidak hanya melihat proses pencarian informasi foodie pada makanan sebagai produk saja tetapi juga hal lain seperti pelayanan restoran, suasana restoran, lokasi restoran dan hal-hal lainnya.

Tahap pertama adalah pengenalan kebutuhan, yaitu sebuah tahap di mana konsumen berada dalam kondisi faktual dan bayangan yang ideal dari informasi yang dilihat atau dibaca. 


\section{Jurnal Komunikasi Nusantara}

\section{E-ISSN. 2685-7650}

Vol. 2 No. 1 (2020), pp 56-66

DOI: https://doi.org/10.33366/jkn.v2i1.40

Pada tahap ini, konsumen mendapati dirinya sedang menghadapi permalasahan dan harus segera mencari informasi untuk menyelesaikan masalah tersebut.

Pada tahap kedua, adalah tahap pengumpulan informasi. Dalam tahap ini konsumen melakukan pencarian informasi secara internal dan eksternal. Pada pencarian internal, konsumen mendapati dirinya terdorong untuk melakukan pencarian informasi karena ada motivasi atau keinginan dari dalam dirinya. Motivasi tersebut bisa didasari pada ingatan terhadap sesuatu, memikirkannya dalam waktu agak lama, atau pengalaman di masa lalu. Karena adanya ketidakpastian, maka dilakukan pencarian informasi secara eksternal. Dalam pencarian informasi secara ekstenal, konsumen menggunakan sumber-sumber informasi seperti internet, media massa, brosur tentang penyedia layanan, bertanya pada keluarga dan teman, serta bertanya pada ahli di bidang tersebut (Tsiotsou \& Wirtz, 2015).

Kemudian setelah semua informasi dirasakan sudah terkumpul maka tahapan berikutnya adalah evaluasi terhadap informasi yang didapatkan. Dalam tahapan ini ada tiga jenis evaluasi. Pertama adalah evaluasi terhadap atribut pencarian, di mana konsumen mengevaluasi informasi yang terkait dengan harga, lokasi, kualitas, dan pertimbangan lain yang bisa menyebabkan kerugian pada diri konsumen. Konsumen mempertimbangkan informasi-informasi tersebut sehingga tidak mengalami banyak kerugian, baik secara materiil maupun fisik (Tsiotsou \& Wirtz, 2015).

Sedangkan jenis evaluasi kedua dilakukan pada atribut pengalaman. Konsumen mempertimbangkan pengalaman di masa lalu terkait dengan penyedia layanan kemudian mengevaluasi memori tersebut. Namun evaluasi pengalaman bisa didapatkan apabila konsumen sudah pernah mencoba penyedia layanan tersebut. Sehingga bisa disimpulkan evaluasi terhadap atribut ini hanya bisa diberlakukan apabila konsumen sudah pernah mendapatkan pengalaman dengan penyedia layanan atau produk (Tsiotsou \& Wirtz, 2015).

Jenis evaluasi ketiga dilakukan pada atribut kepercayaan. Evaluasi ini dapat dilakukan setelah konsumen menggunakan produk/ penyedia layanan dalam waktu yang lama. Evaluasi ini biasanya terjadi pada pelayanan yang memiliki dampak jangka panjang seperti jasa asuransi dan layanan kesehatan.

Dengan menggunakan konsep tersebut, penelitian ini menjawab rumusan masalah penelitian, "bagaimana proses yang dilakukan foodie dalam mencari informasi melalui foto makanan di Instagram?" Penelitian ini bertujuan untuk menggambarkan proses pencarian informasi yang dilakukan oleh foodie pada foto makanan di Instagram. Proses pencarian informasi tersebut meliputi beberapa tahapan yang muncul di level kognitif. Penelitian ini juga ingin melihat cara-cara dan kebiasaan yang dilakukan oleh foodie dalam mencari informasi pada foto makanan di Instagram dan proses pencarian informasi dalam konteks kehidupan sehari-hari non-pekerjaan yaitu hobi kuliner yang dilakukan oleh foodie.

\section{Metode Penelitian}

Metode penelitian yang digunakan adalah analisis deskriptif kualitatif. Metode ini merupakan ringkasan deskriptif dari peristiwa yang diseleksi dan data disajikan dengan cara-cara yang relevan yang disesuaikan dengan tujuan dan targetnya (Creswell, 2013). Disain penelitian ini sangat berguna untuk mengetahui segala aspek yang terkait dengan fenomena/ peristiwa, seperti 


\section{Jurnal Komunikasi Nusantara}

\section{E-ISSN. 2685-7650}

Vol. 2 No. 1 (2020), pp 56-66

DOI: https://doi.org/10.33366/jkn.v2i1.40

pihak/ orang yang terlibat, hal-hal yang terlibat di dalamnya serta lokasi terjadinya fenomena/ peristiwa (Lambert \& Lambert, 2012).

Pemilihan informan diambil berdasarkan karakteristik foodie yang dipaparkan oleh Mohsen (2017). Seorang foodie harus memiliki karakteristik seperti antara lain, menikmati makanan yang dikonsumsinya, bahkan menjadikan jargon "makan untuk hidup" sebagai salah satu ungkapan yang menggambarkan diri seorang foodie, tertarik untuk mempelajari makanan, terinspirasi untuk menjadi foodie karena konten media sosial atau sosok yang ahli dalam makanan atau memasak dari televisi atau majalah, serta karakteristik lainnya.

Pemilihan kategori informan dalam penelitian ini adalah sebagai berikut: (1) Seorang foodie, dengan karakteristik yang telah disebutkan di atas; (2) Memiliki akun Instagram dan aktif menggunakannya untuk keperluan hobinya sebagai seorang foodie; (3) Melakukan salah satu aktivitas foodie, yaitu pernah makan di luar rumah seperti kafe/ restoran/ kedai dan masih melakukannya hingga saat penelitian berjalan.

Penelitian dilakukan di Jakarta dan sekitarnya pada lima orang foodie. Kelima informan ini dipilih secara random dengan menggunakan model snowball. Tiga orang informan berdomisili di Tangerang Selatan dan dua orang informan lainnya tinggal di Jakarta. Wawancara dilakukan di rumah informan dan juga beberapa lokasi di sekitar rumah informan, seperti pusat perbelanjaan dan coffee shop yang tidak begitu jauh dari kediaman informan.

Jakarta dipilih menjadi lokasi penelitian karena merupakan salah satu kota yang memiliki industri kuliner yang berkembang pesat. Selain itu, Jakarta juga merupakan salah satu kota besar di Indonesia yang dikunjungi wisatawan karena kulinernya, di samping karena tempat berbelanjanya yang sangat lengkap. Para foodie yang sudah memiliki banyak pengikut di akun media sosial pun banyak yang berasal dari Jakarta.

Dalam proses pengambilan pemilihan informan, ada beberapa tahapan dilakukan demi mendapatkan informan yang sesuai dengan kriteria subyek penelitian yang telah ditetapkan. Pada tahap pertama, ditelusuri akun-akun Instagram foodie yang ada di Jakarta dan sekitarnya. Identifikasi dilakukan dengan membaca deskripsi di akun Instagram, yang menyebutkan bahwa akun tersebut adalah akun seorang foodie. Dari puluhan akun foodie disaringlah 10 akun yang aktif di Instagram. Kesepuluh akun tersebut diseleksi lagi untuk mendapatkan informan yang paling sesuai dengan kriteria. Hingga akhirnya ada lima orang foodie yang dijadikan informan. Kemudian, kelima foodie tersebut dihubungi melalui pesan singkat di akun Instagramnya atau alamat surat elektronik yang tertera di sana. Koordinasi untuk jadwal dan teknis wawancara dengan informan dilakukan via aplikasi chat Whatsapp.

Wawancara antara peneliti dengan kelima informan tidak hanya melalui satu pertemuan tatap muka. Pada pertemuan pertama, peneliti lebih banyak melakukan observasi dan mengenal informan tentang profil mereka sebagai foodie. Pada pertemuan berikutnya, peneliti mulai menggali data terkait kebiasaan informan dalam mencari informasi dengan Instagram. Informan juga memperagakan dan menunjukkan detil proses yang biasa dilakukan saat mencari informasi terkait makanan atau tempat makan yang dicarinya di Instagram.

Hasil wawancara kemudian ditranskrip secara verbatim. Setelah itu, dilakukan tahap analisis data dengan open coding, axial coding, dan selective coding. Penjabaran temuan penelitian kemudian ditulis secara tematik dan naratif. 


\section{Jurnal Komunikasi Nusantara}

\section{E-ISSN. 2685-7650}

Vol. 2 No. 1 (2020), pp 56-66

DOI: https://doi.org/10.33366/jkn.v2i1.40

\section{Hasil dan Pembahasan}

Pencarian informasi dilakukan dengan beragam motivasi dan tujuan. Salah satunya adalah untuk mengurangi ketidakpastian. Pencarian informasi dilakukan pada aktivitas-aktivitas yang membutuhkan berbagai pertimbangan karena dibutuhkan keputusan pada tujuan akhirnya. Seperti keputusan untuk bertindak (action) atau membeli (purchase).

Foodie, dikenal sebagai orang yang menyukai makanan, dan hobi tersebut diwujudkan melalui aktivitas menikmati kuliner. Untuk mencari informasi yang mendukung hobi tersebut foodie bisa menggunakan bermacam-macam sumber informasi. Dengan perkembangan teknologi digital, foodie kini bisa mengeksplorasi informasi makanan di media sosial.

Instagram, sebagai salah satu media sosial dengan karakteristik user created content $(U C C)$, bisa menjadi salah satu sumber informasi. Dalam penelitian ini, dipaparkan tentang pencarian informasi pada foto makanan di Instagram yang dilakukan oleh foodie. Proses pencarian informasi tersebut terbagi menjadi beberapa tahapan, (1) pengenalan kebutuhan, (2) penelusuran informasi, (3) evaluasi terhadap informasi. Tahapan ini menggunakan konsep pra pembelian pada konsumsi jasa pelayanan dari Tsiotsou dan Wirtz (2015).

\section{Tahap Pengenalan Kebutuhan}

Tahap pengenalan kebutuhan dalam penelitian ini adalah tahap di mana foodie mulai merasakan keinginan untuk mencicipi makanan tertentu dari melihat fotonya di Instagram. Atau, foodie merasakan lapar karena melihat foto makanan di Instagram. Foodie menyampaikan di tahapan ini dengan melihat foto-foto makanan yang menyebabkan timbulnya rasa lapar, atau membuat mereka tiba-tiba ingin mencicipi makanan yang ada di foto tersebut.

Semua informan menyebutkan bahwa konten media sosial, yaitu foto makanan di Instagram menimbulkan keinginan untuk makan atau ada rasa lapar setelah melihatnya. Secara spesifik, foto makanan di Instagram menimbulkan keinginan foodie untuk mencicipi suatu makanan. Keinginan ini kemudian yang membawa mereka untuk melakukan pencarian informasi terhadap foto makanan yang dilihat di Instagram. Hal ini diungkapkan oleh Informan \#1 yang mengungkapkan bahwa meski hanya dengan melihat foto makanan di Instagram saja, bisa membuat dirinya merasa lapar.

"Ini seperti pergi ke restoran terus dikasih buku menu yang menunya banyak banget. Fotofotonya ada yang tidak terlalu cantik, tapi isinya makanan semua. Bikin ngiler." (Informan 1)

Dalam identifikasi pengenalan kebutuhan ketika melihat foto makanan di Instagram, foodie mengungkapkan bahwa mereka menjadi merasa lapar atau muncul keinginan untuk mencicipi makanan yang dilihat tersebut. Dalam tahap tersebut, foodie juga mengalami proses seleksi informasi. Dari puluhan hingga ratusan foto yang ditelusuri di Instagram, foodie memilih foto makanan yang menarik dan melewati foto makanan yang tidak menarik untuk mereka.

Tidak semua foto makanan yang dilihat oleh informan menimbulkan keinginan untuk mencicipi makanan tersebut. Di bagian ini, identifikasi yang dilakukan foodie berbeda-beda. Temuan ini menjadi menarik karena foodie memiliki preferensi masing-masing dalam menentukan kriteria foto makanan yang menarik dan yang tidak menarik. Di antaranya, komposisi, warna dan tampilan penyajian makanan. 


\section{Jurnal Komunikasi Nusantara}

\section{E-ISSN. 2685-7650}

Vol. 2 No. 1 (2020), pp 56-66

DOI: https://doi.org/10.33366/jkn.v2i1.40

"Komposisi (foto) sebenernya nggak begitu pengaruh banget. (Yang berpengaruh) warna makanan dan mungkin penataannya ya? Dua foto ini jenis makanannya sama-sama burger tapi fotonya beda. Yang (foto) ini ada gambar lendir dari telur mentah. Kalau (foto) yang satu ini kan keju. Mungkin kalau keju yang meleleh itu masih bagus. Kalau telur itu kan kayak berlendir gitu lho. Mungkin telur bagus, tapi nggak harus menetes banget gitu kali ya?" (Informan \#1)

Dari hasil wawancara dengan para informan ditemukan bahwa informan juga melakukan proses seleksi dari foto makanan yang dilihatnya di Instagram pada tahap ini. Ada dua hal yang menjadi perhatian para informan dalam menyeleksi foto makanan, yang pertama adalah menu/jenis makanan dan yang kedua adalah tampilan foto makanan yang terlihat menarik.

Hal ini didukung oleh penelitian yang dilakukan oleh Spence (2016), yang menjelaskan bahwa di masa ini, kehadiran media digital dalam kehidupan manusia, turut andil menjadikan makanan berwujud virtual yang kini semakin berlimpah. Kehadiran makanan dalam wujud virtual tersebut bisa membuat orang yang melihatnya menjadi merasa lapar karena melibatkan responrespon secara fisiologis, behavioral dan juga ada perubahan di saraf mereka.

\section{Tahap Pencarian Informasi}

Dalam tahap kedua, yaitu penelusuran informasi, seseorang mengalami proses pencarian informasi secara internal maupun eksternal. Pencarian secara internal terjadi karena ada dorongan, motivasi atau ingatan seseorang yang menyebabkan dirinya kemudian tergerak untuk mencari informasi. Apabila pencarian informasi secara internal dirasakan masih kurang, dan dibutuhkan informasi yang lebih dalam dan detil maka terjadilah proses pencarian informasi secara eksternal.

Dalam tahapan penelusuran informasi secara internal, foodie sudah mengetahui hal-hal yang dibutuhkannya. Namun seringkali informasi tersebut tidak cukup sehingga foodie masih membutuhkan penelurusan informasi secara eksternal. Pencarian informasi secara internal melibatkan ingatan, motivasi, pikiran, dan pengalaman foodie sehingga terdorong untuk melakukan pencarian informasi secara eksternal.

Dari pemaparan para informan, hal internal yang muncul adalah ingatan dan pengetahuan keinginan untuk mencari makanan tertentu atau karena kebutuhan tertentu. Dalam penelusuran informasi yang terjadi pada foodie secara internal, ada beberapa hal yang menjadi latar belakang mereka kemudian melakukan penelusuran informasi secara eksternal. Jawaban dari para informan bisa disimpulkan karena dilatarbelakangi oleh adanya kebutuhan manusia, yaitu rasa lapar.

Rasa lapar juga dikarenakan tiga hal, yang pertama karena pada saat tertentu foodie merasa lapar dan menginginkan sebuah menu makanan tapi masih belum memutuskan untuk mencari tempat makan. Yang kedua adalah rasa lapar yang muncul karena foodie teringat makanan kesukaannya yang kemudian mendorong dirinya untuk menelusuri informasi lebih lanjut di Instagram atau sumber informasi lainnya.

Seperti yang diungkapkan oleh Informan \#3, yang mengungkapkan bahwa dirinya memiliki kebiasaan langsung mencari makanan yang diinginkan saat merasa lapar. Informan \#3 menggunakan tanda pagar dan kata kunci dalam mencari informasi terkait makanan atau lokasi tempat makan yang ingin dikunjungi. 


\section{Jurnal Komunikasi Nusantara}

\section{E-ISSN. 2685-7650}

Vol. 2 No. 1 (2020), pp 56-66

DOI: https://doi.org/10.33366/jkn.v2i1.40

"Misalnya kata kuncinya, makan siang, makan malam. Jarang sih aku memakai hashtag (\#) terus langsung ke nama makanannya misalnya ayam, mie goreng. Aku ketik hashtag dalam bahasa Indonesia ya, soalnya kalau dinner takutnya makanan dari luar. Atau hashtag kuliner Jakarta.” (Informan \#3)

Dalam proses pencarian informasi secara eksternal, maka seseorang akan mencari informasi dari orang-orang terdekatnya seperti keluarga dan teman, atau dari media sosial. Di tahap ini, penelusuran informasi dilakukan untuk mengurangi ketidakpastian dan bentuk antisipasi dari resiko yang mungkin bisa didapat. Resiko yang bisa didapatkan foodie, seperti yang disampaikan oleh para informan, adalah kesesuaian harga dengan kualitas/rasa makanan dan lokasi dengan kualitas/rasa makanan.

Para informan menceritakan bahwa media sosial merupakan sumber utama mereka dalam mencari informasi tentang makanan yang ingin dibeli. Instagram merupakan media sosial utama bahkan satu-satunya untuk semua informan dalam mencari informasi sebelum membeli makanan. Meskipun demikian, setiap informan memiliki pola pencarian yang berbeda-beda dalam mencari informasi foto makanan di Instagram.

Meskipun Instagram menjadi sumber informasi yang diandalkan foodie dalam mencari informasi terkait makanan. Namun ternyata informasi yang diberikan Instagram seringkali belum mencukupi untuk foodie untuk membantu mereka dalam membuat keputusan. Sehingga, foodie sering menggunakan sumber informasi lainnya untuk meyakinkan mereka untuk mengunjungi tempat makan tersebut dan mencicipi makanan yang mereka lihat di Instagram.

Foodie menggunakan sumber lain seperti situs direktori tempat makan pergikuliner.com dan zomato.com. Di situs ini, foodie bisa mendapatkan informasi lebih lengkap karena ulasan yang ditulis oleh orang lain. Kedua situs ini juga diakui memberikan opini dan ulasan yang jujur sehingga foodie mempercayai informasi yang diberikan. Ulasan tersebut sangat membantu foodie dalam memutuskan untuk datang dan makan di tempat tersebut.

"Referensiku sekarang Instagram. Di Instagram itu baru aku baca ulasannya atau kalau aku nggak tahu tempatnya baru ke akun @ pergikuliner kalau enggak ke zomato.com. Mungkin karena memang teman-teman aku kebanyakan foodie. Jadi otomatis lihat kayak Instagram dulu terus baru ke @pergikuliner atau kalau enggak ke zomato.com” (Informan \#5)

Penggunaan sumber informasi dari media sosial lain dan situs direktori restoran selain Instagram dibutuhkan oleh foodie karena mereka begitu tertarik dengan makanan yang mereka lihat di Instagram. Keterlibatan seorang foodie yang begitu tinggi terhadap pencarian informasi menunjukkan bahwa foodie memiliki ketertarikan yang besar terhadap foto makanan yang dilihatnya di Instagram.

Bilgihan dan Kandampully (2014) melakukan penelitian tentang pola perilaku generasi Y dalam mencari informasi tentang restoran. Generasi Y merupakan kelompok mayor dalam industri restoran/makanan. Dijelaskan juga bahwa generasi Y adalah kelompok yang "melek teknologi" serta memberikan porsi waktu dan uangnya untuk teknologi komunikasi. Mereka adalah pengguna jejaring sosial yang masuk dalam kategori "berat", seperti Twitter dan Facebook. Generasi Y sering membagikan informasi dan pengalamannya saat makan di restoran melalui jejaring sosial. 


\section{Jurnal Komunikasi Nusantara}

\section{E-ISSN. 2685-7650}

Vol. 2 No. 1 (2020), pp 56-66

DOI: https://doi.org/10.33366/jkn.v2i1.40

Informasi yang dibagikan inilah yang juga digunakan oleh rekan-rekan sebayanya. Media sosial memiliki kekuatan dalam memberikan informasi dan juga pengaruh kepada keputusan yang diambil oleh generasi Y.

\section{Tahap Evaluasi Informasi}

Dalam tahap evaluasi pada informasi yang didapatkan, foodie melakukan penelusuran informasi sehingga bisa dijadikan pertimbangan untuk mengurangi resiko di masa mendatang ketika akhirnya memutuskan untuk membeli makanan di tempat tersebut. Informasi ini disebut sebagai resiko yang dirasakan. Bahan pertimbangan didapatkan dari tiga tiga atribut, yaitu atribut pencarian, atribut pengalaman dan atribut kepercayaan.

Atribut pencarian disebutkan sebagai informasi atau hal-hal yang dijadikan pertimbangan foodie saat akan membeli makanan. Atribut pencarian adalah hal-hal yang bisa dirasakan oleh foodie, yang kemudian bisa digunakan untuk bahan evaluasi. Beberapa hal yang masuk dalam kategori atribut pencarian antara lain, informasi terkait dengan merek, harga dan biaya transaksi, kualitas produk dan lain-lain. Sedangkan atribut pengalaman adalah bahan pertimbangan foodie sebelum memutuskan untuk membeli makanan atau makan di tempat tersebut karena pengalaman yang didapatnya dahulu setelah membeli makanan atau makan di tempat tersebut.

Atribut kepercayaan bisa digunakan sebagai bahan evaluasi tetapi hanya bisa dirasakan dalam jangka waktu yang lama setelah menggunakan produk/jasa tersebut. Biasanya atribut kepercayaan muncul dalam pembelian produk untuk jangka waktu lama. Atribut kepercayaan seringkali digunakan dalam pembelian produk-produk seperti alat elektronik, kendaraan bermotor dan perangkat gawai. Sedangkan untuk jasa, atribut kepercayaan seringkali digunakan pada sektor jasa yang memiliki dampak jangka panjang seperti kesehatan (rumah sakit) dan finansial (asuransi).

Lokasi menjadi salah satu bahan foodie dalam mengevaluasi informasi dari foto makanan yang dilihatnya. Pertimbangan lokasi menjadi penting ketika diperbandingkan dengan kualitas dan rasa makanan. Mereka lebih memilih untuk makan di lokasi yang tidak begitu jauh dari tempat mereka tinggal meskipun sangat ingin mencicipi makanan tersebut.

"Lokasi jadi pertimbangan. Kalau jauh enggak, cari lagi yang lain. Gue misalnya lagi di Gancit (Gandaria City) nih, misalnya lagi ketemu orang. Gue pengen makan, (tapi) bosan makan di mall. Akhirnya myari makanan di Instagram, misalnya ketemunya di Kelapa Gading. Ya kali gue ke Kelapa Gading, enggaklah! Logika aja kalau gue. Kecuali memang kita sama teman-teman sudah planning mau makan di Kelapa Gading." (Informan \#3).

Selain lokasi, harga juga menjadi evaluasi utama foodie dalam proses pengambilan keputusan. Harga begitu menentukan dalam proses keputusan foodie untuk mencicipi makanan yang mereka lihat di Instagram. Informasi harga oleh foodie juga diperbandingkan dengan jenis makanan, dan kualitas serta rasa makanan.

"Gue biasanya cek harga juga. Nah biasanya ada nih free voucher, wah masih ada promo nih. Misalnya ada mie harganya 12 ribu. Murah banget. Ya udah biasanya kalau gue memang udah cocok, cobain sih." (Informan \#2) 


\section{Jurnal Komunikasi Nusantara}

\section{E-ISSN. 2685-7650}

Vol. 2 No. 1 (2020), pp 56-66

DOI: https://doi.org/10.33366/jkn.v2i1.40

Temuan di atas sesuai dengan beberapa penelitian sebelumnya. Salah satunya tentang harga makanan menjadi faktor penentu konsumen mendatangi restoran. Hal ini diungkapkan dalam penelitian yang dilakukan oleh Gregory dan Kim (2008). Hasil riset dari Akbar dan Alaudeen (2012) mengungkapkan bahwa pengunjung restoran mengevaluasi beberapa hal sebelum mereka memutuskan datang ke sebuah restoran. Di antaranya, suasana sekitar restoran, lokasi, jumlah pengujung restoran, harga, kualitas makanan, kualitas pelayanan serta variasi menu makanan.

\section{Kesimpulan}

Penelitian yang dilakukan terhadap lima orang foodie ini menunjukkan adanya pola pencarian informasi yang dilakukan oleh mereka yang memiliki hobi terkait dengan makanan. Pertama, ada beberapa tahapan yang dilakukan oleh foodie dalam melakukan pencarian informasi pada foto makanan di Instagram. Tahapan tersebut antara lain, pengenalan kebutuhan, penelusuran informasi yang terjadi secara internal dan eksternal, kemudian evaluasi ada informasi yang didapatkan.

Kedua, pada tahap pengenalan kebutuhan pada foodie ditunjukkan dengan respon yang dilakukan foodie setelah melihat foto makanan. Biasanya foodie merasa lapar kemudian mereka mencari informasi makanan di Instagram. Hal ini diakui oleh beberapa informan. Sedangkan informan lainnya, menjadi lapar setelah melihat-lihat foto makanan di Instagram. Para informan memilliki kebiasaan yang berbeda-beda saat mengakses Instagram. Namun kelima informan mengakui makanan merupakan hal utama yang dicari di Instagram.

Ketiga, pada tahap penelusuran informasi, foodie mulai mengumpulkan informasi secara internal seperti keinginan atau ingatan tentang menu makanan tertentu. Namun, karena foodie masih memiliki ketidakpastian terhadap menu makanan tersebut maka dilakukanlah pencarian informasi secara eksternal seperti menggunakan media sosial Instagram dan juga situs direktori restoran untuk membantu mereka mendapatkan informasi tempat makan dan harga. Di tahapan ini ditunjukkan cara-cara informan mencari informasi terkait makanan atau tempat makan. Informan menggunakan pencarian dengan kata kunci dan tanda pagar. Informan juga membaca informasi yang ada pada caption foto makanan yang ada di Instagram. Informasi yang dicari antara lain lokasi dan harga.

Keempat, pada tahap evaluasi terhadap informasi, foodie melakukan evaluasi informasi harga dan lokasi sebagai bahan pertimbangan. Harga tersebut kemudian diperbandingkan dengan kualitas dan rasa makanan. Di tahapan ini semua informan memilih harga makanan yang lebih murah dengan lokasi yang lebih dekat dengan tempat tinggal mereka. Hal ini disebabkan karena Jakarta merupakan kota yang sangat luas. Selain itu kemacetan Jakarta menjadi alasan informan untuk mencari tempat makan yang dekat dengan tempat tinggal mereka.

Penelitian selanjutnya bisa menggunakan pendekatan kuantitatif untuk menguji temuan dari hasil penelitian ini. Dengan pendekatan kuantitatif maka bisa menguji model dari pencarian informasi yang dilakukan oleh foodie. Hal yang bisa dibuktikan adalah media sosial dan situs direktori sebagai sumber informasi serta harga, lokasi dan ulasan konsumen lain sebagai evaluasi terhadap informasi yang didapatkan.

Selain itu, sumber informasi tidak terbatas pada satu media sosial seperti Instagram. Jejaring sosial bisa meliputi media sosial, blog, Wikipedia, forum online, aplikasi mobile dan masih banyak lagi. Sehingga hasil penelitian bisa lebih komprehensif dalam melihat penggunaaan media baru sebagai sumber pencarian informasi yang terkait dengan makanan. 


\section{Jurnal Komunikasi Nusantara}

\section{E-ISSN. 2685-7650}

Vol. 2 No. 1 (2020), pp 56-66

DOI: https://doi.org/10.33366/jkn.v2i1.40

\section{Daftar Pustaka}

Akbar, Y.A.A. \& Alaudeen, M.S.S. (2012). Determinant of factors that influence consumer in choosing normal full-service restaurants: Case in Seri Iskandar, Perak. South East Asian Journal of Contemporary Business, Economics and Law, 1(4), 137-145.

Argus, W. (2017, April 22). Click bait on a plate. The Argus; Cape Town, p. 12.

Bilgihan, A., \& Kandampully, J. (2014). Generation Y's dining information seeking and sharing behavior on social networking sites: An exploratory study. International Journal of Contemporary Hospitality Management, 349-366.

Creswell, J. W. (2013). Research Design: Pendekatan Kualitatif, Kuantitatif dan Mixed Third Edition. Yogyakarta: Pustaka Pelajar.

Elmusharaf, K. (2012). Qualitative Sampling Techniques Training Course in Sexual and Reproductive Health Research Geneva 2012. Geneva: University of Medical Science and Technology.

Gregory, Susan \& Kim, Joohyang. (2008) Restaurant Choice, Journal of Foodservice Business Research, 7:1, 81-95.

Group, H. (2012). Store.hartman-group.com/. Retrieved from http://store.hartmangroup.com/content/social-media-2012-overview.pdf

Johnston, J., \& Baumann, S. (2010). Foodies Democracy and Distinction in the Gourmet Foodscape. New York: Routledge.

Lambert, V. A., \& Lambert, C. E. (2012). Qualitative Descriptive Research: An Acceptable Design. Pacific Rim International Journal of Nursing Research, 255-256.

Mohsen, M. G. (2017). FOODIE IN THE UK: A SENSE OF SELF, CONNECTION AND BELONGING BEYOND THE PASSION? Worcester, UK: University of Worcester.

Safely, C. (2014). A Parent's Guide to Instagram. Contentsafely.org.

Savolainen, R. (2017). Research in Information Science Award: Everyday Life Information Seeking. Bulletin of the Association for Information Science and Technology, FebruaryMarch 2017. Volume 43, No.3, 53-56

Spence, C. (2016). Eating with our eyes: From visual hunger to digital satiation. Brain \& Cognition, 53-63.

Thanarugchok, N. (2017). "Beyond Appetite”: Examining Identities and Motivations of Foodie through Food Visuals on Instagram (Master thesis, University of Washington, Seattle, Washington). Retrieved from http://www.com.washington.edu/wpcontent/uploads/2017/06/Pam-Honors-thesis-final-paper.pdf

Tsiotsou, R. H., \& Wirtz, J. (2015). The Three-Stage Model of Service Consumption. In P. W. Daniels, Handbook of Service Business (pp. 105-128). Edward Elgar.

Zycherman, A. (2014). Food and the Self: Consumption, Production and Material Culture d'Isabelle de Solier. Anthropology of Food, https://aof.revues.org/7641. (8) (PDF) A Conceptual Review of "Foodies" in Tourism. 